\title{
The Governance of Climate Change: Evaluating the Governance Quality and Legitimacy of the United Nations' REDD-plus Programme
}

\author{
Tim Cadman, Australian Centre for Sustainable Business and \\ Development, Faculty of Business, University of Southern \\ Queensland, Australia \\ Tek Maraseni, Australian Centre for Sustainable Catchments, \\ Faculty of Business, University of Southern Queensland, Australia
}

Abstract: This paper outlines the evolution of the concept of global environmental governance, and its expression within climate-change related problem-solving institutions. A number of institutions address climate change on a global level, with a variety of institutional structures and processes. This leads to difficulties for comparative analysis, particularly when it comes to assessing quality of governance. Governance performance is important, since it helps stakeholders determine whether a given institution is sufficiently legitimate to merit participation, or whether their efforts are better served in other forums. Using a sêt of principles, criteria and indicators of governance quality, the paper provides an analysis of the 'REDD-plus' process (United Nations Collaborative Programme on Reducing Emissions from Deforestation and Forest Degradation in Developing Countries). It highlights REDDplus' strengths and weaknesses and provides a rating of institutional legitimacy. It concludes with some observations on the challenges facing REDD-plus, and calls for the development of standards to ensure institutional quality-of-governance.

Keywords: Global Environmental Governance, Climate Change, REDD-plus, Quality-of-Governance, Legitimacy

\section{Introduction}

$\mathrm{I}$ N RECENT YEARS, 'multi-level governance' has been increasingly used as a term to replace the earlier 'regime' concept of international rulemaking, particularly influential in international relations (IR) theory. ${ }^{1}$ This follows on from a body of work that has arisen over the past two decades or so, which argues for a broader understanding of state and non-state relations than those explained by traditional top-down, command-control models of state authority. Modern governance is portrayed as essentially social-political in nature, consisting of a variety of 'co'arrangements between state and non-state actors, built around collaborative approaches to problem solving. ${ }^{2}$ Contemporary environmental governance, which is exemplified by the interactions that occur between multiple actors within decentralised networks functioning at all levels, demonstrates this drift especially

\footnotetext{
${ }^{1}$ Kees Van Kersbergen and Frans Van Waarden, “'Governance' as a Bridge Between Disciplines: Cross-disciplinary Inspiration Regarding Shifts in Governance and Problems of Governability, Accountability and Legitimacy", European Journal of Political Research 43 (2004), pp. 143-171, at p. 149.

2 Jan Kooiman, "Findings, Speculations and Recommendations", in Modern Governance: New Government Society Interactions ed. Jan Kooiman (London: Sage, 1993), pp. 249-262, at pp. 250-251.
} 
strongly. ${ }^{3}$ Forest management represents one of the best policy arenas in which to study the new types of governance that have arisen in response to the economic, social and environmental dynamics of globalisation. ${ }^{4}$ This is because it is the forestry sector specifically that demonstrates some of the most extensive and innovative experiments in 'new' governance. ${ }^{5}$ REDD-plus is one of the most interesting of these. This paper examines REDD-plus in the light of contemporary developments in governance theory and analysis. It utilises an evaluative framework through which some of the different sub-institutions associated with REDD-plus can be evaluated and compared, based on eleven quality-of-governance indicators. Included are the results of two stakeholder surveys, conducted between October and November 2009 and March and April 2010 (before and after the Copenhagen Conference of Parties COP 15). These look at three institutional components of REDD-plus: the United Nations Framework Convention on Climate Change REDD-plus related negotiations (UNFCCC-REDD-plus); the United Nations REDD Programme (UN-REDD); and the Forest Carbon Partnership Facility (FCPF). It concentrates on two of the most important sets of actors involved in REDD-plus negotiations: environmental NGOs and government representatives from both the global North and global South.

\section{REDD-plus: description and background}

It is widely recognised that without reducing emissions from deforestation and forest degradation the $2^{\circ} \mathrm{C}$ ( or 450 parts per million of $\mathrm{CO}_{2}$ ) climate stabilization goal will be difficult to achieve. REDD has potential to address a source of greenhouse gas (GHG) emissions larger than the entire global transportation sector. ${ }^{6}$ Deforestation and forest degradation account for nearly $20 \%$ of global greenhouse gas (GHG) emissions, more than the entire global transportation sector and second only to the energy sector. ${ }^{7}$ Towards 2030, forest-related climate change mitigation measures could contribute to more than a third of all $\mathrm{CO}_{2}$ emissions reductions. The IPCC estimates that to reach total forest mitigation potential, $35 \%$ can be fulfilled through reduced emissions from deforestation and degradation, $35 \%$ through improved management including the restoration of degraded forests, and $30 \%$ through afforestation and reforestation activities. ${ }^{8}$ Deforestation shows signs of decreasing in

3 Peter Haas, "UN Conferences and Constructivist Governance of the Environment", Global Governance 8: 1.(2002), pp. 73-91, at p. 74, Peter Glück, Jeremy Rayner, Benjamin Cashore, "Changes in the Governance of Forest Resources", in Forests in the Global Balance ed. G. Mery, R. Alfaro, M. Kaninnen, and M. Lobovikov (Helsinki: IUFRO, 2005), pp. 51-74, at p. 51.

${ }^{4}$ Bas Arts, "Non-state Actors in Global Governance: New Arrangements Beyond the State", in New Modes of Governance in the Global System: Exploring Publicness, Delegation and Inclusiveness ed. Mathias Koenig-Archibugi and Michael Zürn (Basingstoke: Palgrave Macmillan, 2006), pp. 177-200, at p. 178.

${ }^{5}$ Peter Glück, Jeremy Rayner, Benjamin Cashore, "Changes in the Governance of Forest Resources", in Forests in the Global Balance ed. G. Mery, R. Alfaro, M. Kaninnen, and M. Lobovikov. (Helsinki: IUFRO 2005), pp. 51-74 at pp. 55-64.

${ }^{6}$ Arild Angelsen, Sandra Brown, Cyril Loisel and Leo Peskett, Charlotte Streck and Daniel Zarin, Reducing Emissions from Deforestation and Forest Degradation (REDD): An Options Assessment Report (No location: Meridian Institute, 2009) http://www.redd-oar.org/links/REDD-OAR_en.pdf, accessed $18 / 05 / 2010$.

${ }^{7}$ UN REDD Programme "About REDD-plus",

http://www.un-redd.org/AboutREDD/tabid/582/language/en-US/Default.aspx, accessed 20/05/2010.

${ }^{8}$ International Union for the Conservation of Nature (IUCN), REDD-plus: Scope and Options for the Role of Forests in Climate Change Mitigation Strategies (Washington: IUCN, 2009), http://cmsdata.iucn.org/downloads/redd_scope_english.pdf, accessed 21/05/2010. 
several countries but continues at a high rate in others. Around 13 million hectares of forest were converted to other uses or lost through natural causes each year in the last decade compared to 16 million hectares per year in the 1990s. Afforestation and natural expansion of forests in some countries and regions have reduced the net loss of forest area significantly at the global level. The net change in forest area in the period 2000-2010 is estimated at -5.2 million hectares per year (an area about the size of Costa Rica), down from -8.3 million hectares per year in the period 1990 $2000 .^{9}$

REDD addresses the problem of climate change via a range of state and non-state market-based mechanisms to encourage sustainable management of tropical forests, and thereby reduce greenhouse gas emissions. It is now formally referred to as REDD-plus in the wake of COP 15, to reflect the initiative's growing emphasis on conserving and enhancing forests on the basis of their value for carbon sequestration, rather than simply reducing emissions. ${ }^{10}$ REDD-plus includes carbon accounting from the following activities: reducing emissions from deforestation; reducing emissions from forest degradation; conservation of forest carbon stocks; sustainable management of forest; and enhancement of forest carbon stocks (these may be afforestation, reforestation and restoration activities on deforested and degraded lands). ${ }^{11}$ Carbon accounting refers to measuring and analysing GHG emissions and removals from all human induced activities. It includes estimation of baseline, additionality, buffers and discounts, and monitoring, reporting and verification (MRV). No approved forest carbon methodology is yet available to verify reduced emissions associated with reduced impact logging outside of the U.S. ${ }^{12}$

In the Copenhagen Accord developed countries committed USD \$30 billion for the period 2010-2012 with balanced allocation between adaptation and mitigation. Part of this fund goes to REDD-plus. ${ }^{13}$ UN REDD has further predicted that financial flows for GHG emission reductions from REDD-plus could eventually reach up to USD \$30 billion a year. This significant North-South flow of funds would reward substantive reductions of carbon emissions and has the potential to support new, pro-poor development, help conserve biodiversity and secure vital ecosystem services. Effective implementation of REDD-plus could reduce global deforestation by as much as $50 \%$ by 2020 , and to zero percent by $2030 .{ }^{14}$ There are three principle REDD-plus-related mechanisms: the UNFCCC, responsible for the intergovernmental negotiations regarding the content and format of REDD-plus; The UN-REDD, which manages the technical and financial components of the initiative at the international and nationaldevel and is supported by the United Nations Development Programme

\footnotetext{
${ }^{9}$ Food and Agriculture Organisation (FAO), Global Forest Resources Assessment 2010: Key Findings (Rome: FAO, 2010), http://foris.fao.org/static/data/fra2010/KeyFindings-en.pdf, accessed 20/05/2010

${ }^{10}$ For more information, see: Charlie Parker, Andrew Mitchell, Mandar Trivedi and Niki Mardas, The Little REDD-plus Book (Oxford: Global Canopy Programme, 2009), pp. 11- 92.

${ }^{11}$ Allison Bleaney, Leo Peskett, David Mwayafu, "REDD-plus After Copenhagen: What Does it Mean on the Ground?” REDD-NET COP 15 Briefing, January 2010, http://6823165678770790248-a-redd-net-org-s-sites.googlegroups.com/a/redd-net.org/site/files/COP15outcome-webfinal.pdf, accessed 20/05/2010.

${ }^{12}$ Bronson Griscom, David Ganz, Nicole Virgilio, Fran Price, Jeff Hayward, Rane Cortez, Gary Dodge, Jack Hurd, Frank L. Lowenstein, Bill Stanley, The Hidden Frontier of Forest Degradation: A Review of the Science, Policy and Practice of Reducing Degradation Emissions (Arlington, VA: The Nature Conservancy, 2009),

http://www.rainforest-alliance.org/resources/documents/hidden_degradation.pdf, accessed 21/06/2010.

${ }_{13}$ Bleany et al, op. cit.

${ }^{14}$ Angelsen et al, op. cit.
} 
(UNDP), The Food and Agriculture Organisation (FAO) and the United Nations Environment Programme (UNEP); and The World Bank Forest Carbon Partnership Facility (FCPF), which via the Bank's Strategic Climate Fund Forest Investment Programme (FIP), allocates funding aimed at maintaining standing forests by encouraging biodiversity conservation and sustainable use through a range of countrylevel projects. National governments and some NGOs such as The Nature Conservancy (TNC) provide funds for the initiative. ${ }^{15}$

The 'plus' in REDD-plus has also widened the scope of the mechanism to include conservation and enhancement of forest carbon stocks, as well as the sustainable management of forests (SMF). This means that activities such as improved management of protected areas, forest plantations and restoration, and reduced impact logging may yet be elements of REDD-plus strategies. The definition of $\mathrm{SMF}_{2}$ and specifically how it will be distinguished from 'sustainable forest management' (SFM) is not yet clear. However, the definition is certain to cover many of the communitybased forest management practices undertaken by local communities and Indigenous peoples. The broadening of REDD to REDD-plus is generally seen as a positive move. ${ }^{16}$ As there is no final and binding REDD-plus agreement, nothing in the COP 15 draft text can be described as certain. However, negotiators at COP 15 did reach consensus on a number of key issues, which are extremely dikely to be part of any agreement when it is reached. There is still ample opportunity for forest sector stakeholders to influence REDD-plus negotiations to ensure progressive and equitable outcomes benefiting both people and forests. ${ }^{17}$ Ufitimately, the success of an international REDD-plus mechanism will depend on the existence of governance arrangements that are able to deliver emission reductions at scale. To ensure transparency and inclusiveness, decision-making processes, it is argued, should include a system that engages representatives of forest dependent people, civil society organizations, and the private sector. At the national level of implementation, governance arrangements, combined with verification and certification, it has been concluded, should follow a set of minimum standards. ${ }^{18}$

\section{Analytical Framework}

The 'government to governance transition' inherent in contemporary global environmental politics has led to an increased scholarly focus on institutional quality. Studies have tended to focus on governance arrangements, referring to a range of specific attributes influencing "the interaction between various actors pursuing

\footnotetext{
${ }^{15}$ UN-REDD, "The UN-REDD Programme"

http:/www.un-redd.org/UNREDDProgramme/tabid/583/language/en-US/Default.aspx, accessed 23/03/2010; Anita Gordon, Stephanie Tam, Benoit Bosquet and Andre Rodrigues Aquino, Forest Carbon Partnership Facility (Washington: Forest Carbon Finance Facility, undated), http://www.forestcarbonpartnership.org/fcp/sites/forestcarbonpartnership.org/files/Documents/PDF/En glish_54462_WorldBank_FCPF_Brochure.pdf, accessed 21/06/2010,pp. 6-10.

${ }^{16}$ The Centre for People and Forests (RECOFT), REDD-plus: Moving Forward for People and Forests (Bangkok: RECOFT, 2010),

http://www.recoftc.org/site/fileadmin/docs/publications/The_Grey_Zone/2010/REDD_2010_Moving FINAL.pdf, accessed $18 / 05 / 2010$; Bleaney et al, op. cit.

${ }^{17}$ RECOFT, op. cit.

${ }^{18}$ Charlotte Streck, Luis Gomez-Echeverri; Pablo Gutman; Cyril Loisel; Jacob Werksman, REDD+ Institutional Options Assessment: Developing an Efficient, Effective, and Equitable Institutional Framework for REDD+ under the UNFCCC, http://www.redd-oar.org/links/REDD+IOA_en.pdf, accessed 21/05/2010.
} 
common goals." 19 Taken together, these arrangements cover matters of accountability, behavioural change, equality, decision-making, deliberation (or dialogue), dispute settlement (or conflict resolution), implementation, inclusiveness, interest representation, participation, problem solving, resources (or capacity) and transparency. New research on global governance and its relation to sustainable development and natural resource management (forestry) has advanced an analytical framework, which synthesises these previously separate arrangements around the two core features of any governance system: structure and process. ${ }^{20}$ The structural components of contemporary governance focus on those actors that are considered to be relevant participants. The process elements concern the deliberations within the institution in question relating to decision making and implementation. These core governance features of 'structure as participation' and 'process as deliberation' are articulated within a set of principles, criteria and indicators (PC\&I) to determine the degree to which they are demonstrated within a given institution (or sub-institution), in this case REDD-plus.

A principle is a value or rule to be measured. A criterion is a condition, or category of that principle. Principles and criteria are not usually measured directly to provide an estimation of the levels of compliance. As a result they are associated with indicators that are located in a hierarchically subordinate position and link back to the associated criterion, and its relevant principle. They can represent either qualitative or quantitative parameters, and do indicate the state, or condition, of a given system. ${ }^{21}$ By placing these governance arrangements in such a framework it is possible to locate them at the correct level for consistent analysis via indicators to criteria and subsequently to principles. Ensuring that these elements are consistently placed at the appropriate level is important so as to avoid overlap or duplication at another. ${ }^{22}$ See Table 1 below.

Table 1 Hierarchical framework for the assessment of governance quality

\begin{tabular}{|c|c|c|}
\hline Principle & Criterion & Indicator \\
\hline \multirow[t]{5}{*}{ "Meaningful participation" } & \multirow[t]{3}{*}{ Interest representation } & Inclusiveness \\
\hline & & Equality \\
\hline & & Resources \\
\hline & \multirow[t]{2}{*}{ Organisational responsibility } & Accountability \\
\hline & & Transparency \\
\hline \multirow[t]{6}{*}{ "Productive deliberation" } & \multirow[t]{3}{*}{ Decision making } & Democracy \\
\hline & & Agreement \\
\hline & & Dispute settlement \\
\hline & \multirow[t]{3}{*}{ Implementation } & Behavioural change \\
\hline & & Problem solving \\
\hline & & Durability \\
\hline
\end{tabular}

Source: Cadman, 2009

\footnotetext{
${ }^{19}$ Mathias Koenig-Archibugi, “Introduction: Institutional Diversity in Global Governance”, in New Modes of Governance in the Global System: Exploring Publicness, Delegation and Inclusiveness Mathias Koenig-Archibugi, and Michael Zürn (Basingstoke and London: Palgrave Macmillan, , 2006) pp. 1-30, at p. 24, Footnote 13.

${ }^{20}$ Timothy Cadman, Quality and Legitimacy of Global Governance: Case Lessons from Forestry (London: Palgrave, forthcoming)

${ }^{21}$ Erik M. Lammerts van Beuren and Esther M. Blom, Hierarchical Framework For The Formulation Of Sustainable Forest Management Standards (Leiden: The Tropenbos Foundation, 1997), pp. 20-34.

${ }^{22}$ Ibid, pp. 5-9.
} 
In this framework the key governance concept of legitimacy, identified by many scholars, is not directly included, as it is understood as the end point of activity within the institution. Here, it is determined by the degree of successful interaction between the governance system's structural and procedural components, i.e. an integrating model. Previous schools of thought have tended to focus on either input legitimacy ('the means justify the ends'), or output legitimacy ('the ends justify the means'). ${ }^{23}$ The normative concept being stressed here is that the ends and means are equally important. Both are related and consequential one to another and both play a role in legitimacy. This is expressed diagrammatically in Figure 1 below.

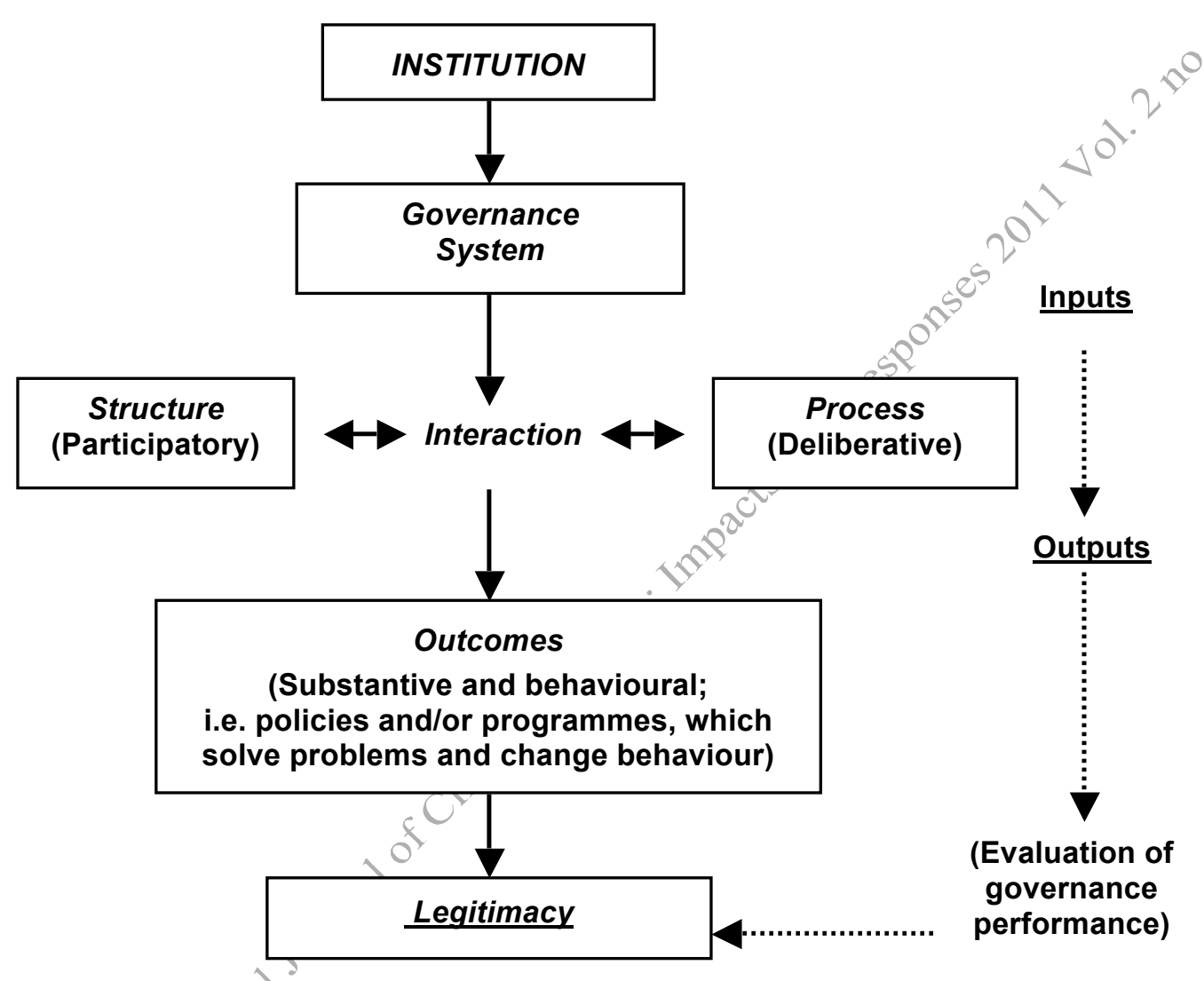

Figure 1: Normative model of contemporary institutional legitimacy (Cadman 2009, adapted)

\section{Method}

Building on this framework and model, the research itself consists of two surveys and three associated questionnaires covering UNFCCC REDD-related negotiations, UNREDD and FCPF. The results provided below represent the views of environmental NGOs and governmental representatives, two sectors in the climate policy arena that could be portrayed as constituting the two 'poles' along the non-state/state

23 Anne Mette Kjaer, Governance (Cambridge and Malden MA: Polity Press, 2004), pp. 7-12 and citing Fritz W. Scharpf, Games Real Actors Play. Actor-Centered Institutionalism in Policy Research (Boulder CO: Westview Press, 1997), p. 153. 
governance continuum. ${ }^{24}$ The surveys asked these participants to rate their perceptions of the governance performance of all three institutional components, using a series of questions based on the indicators of Table 1 above. Each survey was 'static', i.e. collected over a single period in time (approximately one month). The surveys were deployed pre- and post-COP 15. Participants were asked to rate their perceptions of the performance of the three institutional sub-components anonymously, by means of the Internet tool SurveyMonkey, using a Likert scale from 'very high' to 'very low' (1-5), rounded to the second decimal point. The scores of the relevant indicators were added to determine performance at the criterion level. In turn, the relevant criteria were added to determine performance at the principle level; finally, the two principle scores were combined to determine overall performance (see Tables 2-5). In order to compare perceptions, respondents were stratified into four sub-groups: (1) environment North; (2) environment South; (3) government North; and (4) government South. Using standard statistical methods, the average ratings of each of the four sub-groups were in turn used to calculate the weighted averages for the two main groups (environment and government). In order to ascertain the overall perceptions of all respondents, combined weighted averages were subsequently also evaluated and compared.

Perceptions of all groups and sub-groups for each of the three institutional subcomponents are presented in tabular form (Table 2-4). Where they exist, the results from the first survey are included (the rows of stippled grey in each of the tables). A single 'grand total' table is also included, combining the weighted average ratings across indicators and sub-institutional components, which could be taken as the 'legitimacy rating' for REDD-plus as a whole (Table 5). Participants were recruited variously, either from publicly available Internet lists of named individuals active in UNFCCC REDD-related negotiations, UN-REDD and FCPF who were encouraged to circulate the invitation more widely.

Respondents differed across suryeys and questionnaires, although communications from individuals to the researcher indicate that there was some continuity across both surveys and questionnaires. Given the anonymous nature of the survey, it has not been possible to quantify this amount. The numbers of participants are listed in the tables below; bracketed figures represent the numbers of participants in the first survey. It should be stressed however, that given the number of participants and the restricted sets of interests surveyed, the results are anecdotal, rather than authoritative.

\section{Summary discussion of results}

The results associated with each sub-institution and for REDD-plus overall can be found in Tables 2-5 below. It is perhaps not surprising that governments, the main players in global climate change negotiations should generally rate the governance quality of REDD-plus higher than environmental NGOs, who, it is fair to say, are accorded a lesser, informal, status - even if they may actively lobby on the sidelines. Conversely, however, one particularly interesting feature of all the questionnaires is the generally higher rating given by the global South - both governmental and

\footnotetext{
${ }^{24}$ Andrew Jordan, Rüdiger K. W. Wurzel and Anthony Zito, “The Rise of 'New' Policy Instruments in Comparative Perspectives: Has Governance Eclipsed Government?” Political Studies 53 (2005) pp. 441-469, at pp. 492-494. There the poles are governance-to-government, but the argument has been extended here to encompass state-to-non-state interests along a continuum of governance authority.
} 
environmental NGOs. This might seem to indicate that as an initiative 'for' the South some of the traditional North/South imbalances are reversed.

There are a number of universal governance issues identified across the subinstitutions of REDD-plus. The most obvious is the low rating regarding the provision of resources to participate meaningfully in REDD-plus. Scholars point to the need for money and expertise as a structural framework condition for developing environmental policy capable of resolving ecological problems. ${ }^{25}$ There was also a general low score for dispute settlement. When conflict occurs within negotiations, or as a result of complaints over procedure, several sources identify the need for disputeresolution mechanisms. ${ }^{26}$ The breakdown of processes of engagement and negotiation and the inability to resolve conflicts have been identified as two key indicators of governance failure. ${ }^{27}$ Despite their central importance to quality of governance, there should be some concern over the relatively unimpressive ratings across institutions for accountability and transparency. Governance structures need to be sufficiently robust to address accountability at the multiple levels of contemporary global governance. ${ }^{28}$ Formal structures and clearly defined rules are required, otherwise transparency can be lost, and policy making predetermined. ${ }^{29}$ Conversely, respondents almost universally provided relatively high ratings for REDD-plus' implementation capacity. At this stage these views are speculative as the negotiations are as yet incomplete and the on-the-ground projects still in the early stages of formation, but it nevertheless demonstrates a degree of optimism regarding REDD-plus' ability over time to change behaviour contributing to, and tackle the problem of, deforestation and forest degradation in developing countries. This is encouraging since "an institution is effective if it contributes significantly to solving the problems that motivated its establishment, notably by shaping the behaviour of relevant target groups.",30

25 Michael Mason, Environmental Dêmocracy, (New York: St Martin's Press, 1999), pp. 72-73. See also Martin Jänicke, "Conditions for Environmental Policy Success: An International Comparison", The Environmentalist 12 (1992), pp. 47-58, "Democracy as a Condition for Environmental Policy Success: the Importance of Non-institutional Factors", in Democracy and the Environment: Problems and Prospects, ed. William M. Lafferty and James Meadowcroft (Cheltenham and Lyme: Edward Elgar Publishing, 1996), pp. 71-85; “The Political System's Capacity for Environmental Policy", in Successful Environmental Policy: A Critical Evaluation ed. Martin Jänicke and Helmut Weidner, (Springer: Berlin, 1997).

26 Martijn Van Vliet, "Environmental Regulation of Business: Options and Constraints for Communicative Governance", in Modern Governance: New Government Society Interactions ed. Jan Kooiman (London: SAGE Publications, 1993) pp. 105-118, at p. 111; Errol Meidinger, "The Administrative Law of Global Private-public Regulation: The Case of Forestry", The European Journal of International Law 17 (1) (2006), pp. 47-87, p. 25-27, Elinor Ostrom, Governing the Commons: the Evolution of Institutions for Collective Action (Cambridge: Cambridge University Press, 1990), p. 90.

${ }^{27}$ Gerry Stoker, "The Challenge of Urban Government" in Debating Governance: Authority, Steering and Democracy, ed. Jon Pierre, (Oxford: Oxford University Press, 2000) pp. 91-109, at pp. 100-105.

${ }^{28}$ Katharine N. Farrell, "Recapturing Fugitive Power: Epistemology, Complexity and Democracy", Local Environment 9 (5) (2004), pp. 469-470, at p. 476.

${ }^{29}$ Gerald Berger, "Reflections on Governance: Power Relations and Policy Making in Regional Sustainable Development”, Journal of Environmental Policy and Planning, 5 (3) (2003), pp. 219-234, at pp. 224-225.

30 Jon Birger Skjærseth, Olav Schram Stokke and Jørgen Wettestad, "Soft Law, Hard Law, and Effective Implementation", Global Environmental Politics 6 (3) (2006), pp. 104-120, at p. 105, footnote 11, following Arild Underdal, "The Concept of Regime Effectiveness", Cooperation and Conflict 27 (1992), pp. 227-240 (authors' emphasis). 


\section{Concluding comments}

The opportunity presented by REDD-plus is unprecedented but the risks are considerable. To ensure it fulfils expectations and becomes part of the solution to climate change and not part of the problem will require a reliable monitoring system, which is robust, broad-based, transparent, integrated, inclusive, truly independent and capable of addressing governance realities on the ground. ${ }^{31}$ It is difficult, however, to draw any firm conclusions from such a short-term study, and one with relatively few participants. This paper should therefore be seen as developing some insights into the quality of governance and institutional legitimacy of REDD-plus, but not definitive in its own right. If the findings from these surveys are to be used to argue for a systemic improvement of sub-institutional governance across the REDD-plus mechanisms, longer-term investigation will be necessary to determine if the trends identified here are correct. Nevertheless, the methodology adopted here has the potential to be applied at all spatial levels of REDD-plus, global, regional, national, or local. ${ }^{32}$ It also allows for the creation of standards that can serve as a reference for monitoring, reporting and verifying institutional performance across these levels. ${ }^{33}$ It would be entirely possible to develop quality-of-governance standards out of the framework used in this study that could be applied at the global, national and local levels of REDD-plus. Social political interactions around climate change management are increasingly occurring beyond the confines of the unitary state, and in multi-level, multi-stakeholder contexts. In such spaces, governance standards may be the only means by which institutional legitimacy can be assured. Quality-of-governance standards will make it easier for potential participants to determine whether they should engage in a given initiative or not. There is currently a deal of uncertainty over the legitimacy of some systems, and whether participation has the potential to result in unwarranted institutional legitimacy ${ }_{2}$ Governance standards would allow stakeholders to determine for themselves, on the basis of empirical evidence, rather than engage, and hope for the best.

\footnotetext{
${ }^{31}$ Global Witness, Building Confidence in REDD, Monitoring Beyond Carbon, (London: Global Witness, 2009)

http://www.globalwitness.org/media_library_get.php/1196/1277101361/building_confidence_in_redd_ finalen.pdf, accessed 21/06/2010.

${ }^{32}$ Lammerts van Beuren and Blom, op. cit. p. 7. It is noted however that: "specific spatial levels may require additional principles particularly relevant to that level" (ibid).

${ }^{33}$ Op. cit., p. 34.
} 


\section{References}

Angelsen, Arild, Sandra Brown, Cyril Loisel and Leo Peskett, Charlotte Streck and Daniel Zarin, 2010, Reducing Emissions from Deforestation and Forest Degradation (REDD): An Options Assessment Report (No location: Meridian Institute, 2009) http://www.reddoar.org/links/REDD-OAR_en.pdf, accessed $18 / 05 / 2010$.

Arts, Bas, 2006, "Non-state Actors in Global Governance: New Arrangements Beyond the State", in New Modes of Governance in the Global System: Exploring Publicness, Delegation and Inclusiveness ed. Mathias Koenig-Archibugi and Michael Zürn. London: Palgrave Macmillan, pp. 177-200.

Berger, Gerald, 2003, "Reflections on Governance: Power Relations and Policy Making in Regional Sustainable Development", Journal of Environmental Policy and Planning, 5 (3), pp. 219234.

Bleaney, Allison, Leo Peskett, David Mwayafu, 2010, "REDD-plus After Copenhagen: What Does it Mean on the Ground?" REDD-NET COP 15 Briefing, January 2010, http://6823165678770790248-a-redd--net-org-s-sites.googlegroups.com/a/reddnet.org/site/files/COP15outcome-webfinal.pdf, accessed 20/05/2010.

Cadman, Timothy, forthcoming, Quality and Legitimacy of Global Governance:Case Lessons from Forestry. London: Palgrave Macmillan.

FAO, 2010, Global Forest Resources Assessment 2010: Key Findings. Rome: FAO, http://foris.fao.org/static/data/fra2010/KeyFindings-en.pdf, accessed 20/05/2010

Farrell, Katharine N., 2004, "Recapturing Fugitive Power: Epistemology, Complexity and Democracy", Local Environment 9 (5) pp. 469-470

Global Witness, 2009, Building Confidence in REDD, Monitoning Beyond Carbon. London: Global Witness, http://www.globalwitness.org/media_library_get.php/1196/1277101361/building_confidence_ in_redd_finalen.pdf, accessed 21/06/2010.

Glück, Peter, Jeremy Rayner, Benjamin Cashore,2005, "Changes in the Governance of Forest Resources", in Forests in the Global Balance ed. G. Mery, R. Alfaro, M. Kaninnen, and M. Lobovikov. Helsinki: IUFRO, pp. 51-74.

Gordon, Anita, Stephanie Tam, Benoit Bosquet and Andre Rodrigues Aquino, 2010, Forest Carbon Partnership Facility (Washington: Forest Carbon Finance Facility, undated), http://www.forestcarbonpartnership.org/fcp/sites/forestcarbonpartnership.org/files/Documents /PDF/English_54462_WorldBank_FCPF_Brochure.pdf, accessed 21/06/2010.

Griscom, Bronson, David Ganz, Nicole Virgilio, Fran Price, Jeff Hayward, Rane Cortez, Gary Dodge, Jack Hurd, Frank L. Lowenstein, Bill Stanley, 2009, The Hidden Frontier of Forest Degradation: A Review of the Science, Policy and Practice of Reducing Degradation Emissions. Arlington, VA: The Nature Conservancy, http://www.rainforest-alliance.org/resources/documents/hidden_degradation.pdf, accessed $21 / 06 / 2010$.

Haas, Peter, $U N$ Conferences and Constructivist Governance of the Environment", Global Governance 8: 1 (2002), pp. 73-91.

IUCN, 2009, REDD-plus: Scope and Options for the Role of Forests in Climate Change Mitigation Strategies. Washington: IUCN, http://cmsdata.iucn.org/downloads/redd_scope_english.pdf, accessed 21/05/2010.

Jänicke, Martin, 1992, "Conditions for Environmental Policy Success: An International Comparison”, The Environmentalist 12, pp. 47-58.

_ 1996, "Democracy as a Condition for Environmental Policy Success: the Importance of Noninstitutional Factors", in Democracy and the Environment: Problems and Prospects, ed. William M. Lafferty and James Meadowcroft. Cheltenham and Lyme: Edward Elgar, pp. 7185.

1997, “The Political System's Capacity for Environmental Policy”, in Successful Environmental Policy: A Critical Evaluation ed. Martin Jänicke and Helmut Weidner. Springer: Berlin, pp. 118.

Jordan, Andrew, Rüdiger K. W. Wurzel and Anthony Zito, 2005, “The Rise of 'New' Policy Instruments in Comparative Perspectives: Has Governance Eclipsed Government?" Political Studies 53, pp. 441-469 
Koenig-Archibugi, Mathias, 2006, "Introduction: Institutional Diversity in Global Governance", in New Modes of Governance in the Global System: Exploring Publicness, Delegation and Inclusiveness Mathias Koenig-Archibugi, and Michael Zürn. Basingstoke and London: Palgrave Macmillan, pp. 1-30.

Kooiman, Jan, 1993, "Findings, Speculations and Recommendations", in Modern Governance: New Government Society Interactions ed. Jan Kooiman. London: Sage, pp. 249-262.

Lammerts van Beuren, Erik M. and Esther M. Blom, 1997, Hierarchical Framework For The Formulation Of Sustainable Forest Management Standards. Leiden: The Tropenbos Foundation.

Mason, Michael, 1999, Environmental Democracy. New York: St Martin’s Press.

Meidinger, Errol, 2006, "The Administrative Law of Global Private-public Regulation: The Case of Forestry", The European Journal of International Law 17 (1), pp. 47-87.

Ostrom, Elinor, 1990, Governing the Commons: the Evolution of Institutions for Collective Action. Cambridge: Cambridge University Press.

Parker, Charlie, Andrew Mitchell, Mandar Trivedi and Niki Mardas, 2009, The Little REDD-plus Book. Oxford: Global Canopy Programme.

RECOFT, 2010, REDD-plus: Moving Forward for People and Forests. Bangkok: RECOFT, http://www.recoftc.org/site/fileadmin/docs/publications/The_Grey_Zone/2010/REDD_2010_ MovingFINAL.pdf, accessed $18 / 05 / 2010$.

Skjærseth, Jon Birger, Olav Schram Stokke and Jørgen Wettestad, 2006, "Soft Law, Hard Law, and Effective Implementation”, Global Environmental Politics 6 (3), pp.104-120.

Stoker, Gerry, "The Challenge of Urban Government" in Debating Governance: Authority, Steering and Democracy, ed. Jon Pierre. Oxford: Oxford University Press, pp. 91-109.

Van Kersbergen, Kees and Frans Van Waarden, 2004, “'Governance' as a Bridge Between Disciplines: Cross-disciplinary Inspiration Regarding Shifts in Governance and Problems of Governability, Accountability and Legitimacy”, European Journalof Political Research 43, pp. 143-171.

Van Vliet, Martijn, 1993, "Environmental Regulation of Business: Options and Constraints for Communicative Governance", in Modern Governance: New Government Society Interactions ed. Jan Kooiman. London: Sage, pp. 105-118.

UN-REDD, 2010, “About REDD-plus”, http://www.un-redd.org/AboutREDD/tabid/582/language/en-US/Default.aspx, accessed 20/05/2010.

, "The UN-REDD Programme"

http://www.un-redd.org/UNREDDProgramme/tabid/583/language/en-US/Default.aspx, accessed 23/03/2010. 


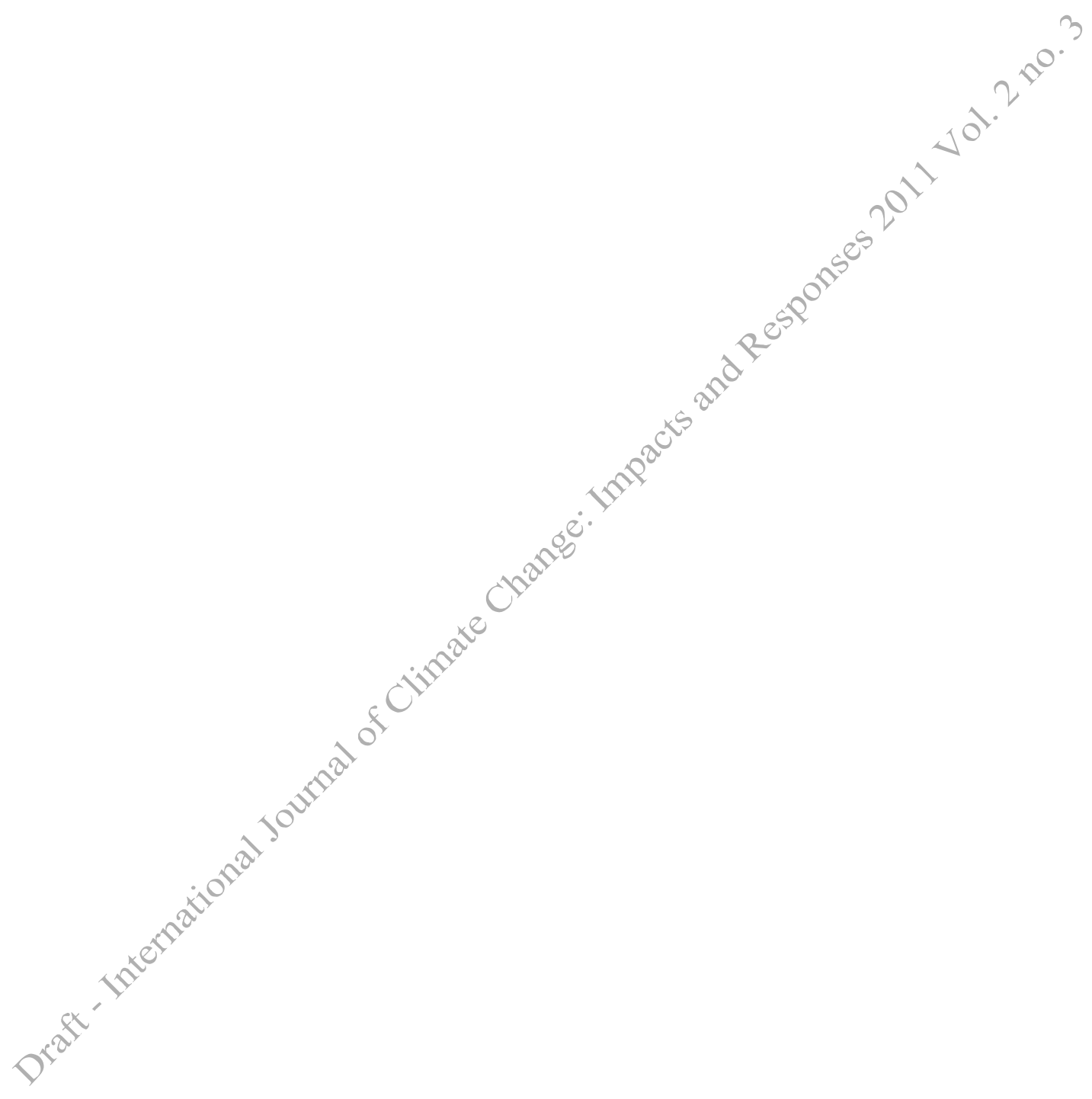


Table 2: UNFCCC-REDD-plus related questionnaire (figures in brackets and aqua blue colours contain the results of the first survey)

\begin{tabular}{|c|c|c|c|c|c|c|c|c|c|c|c|c|c|c|c|c|c|c|}
\hline \multirow{3}{*}{$\begin{array}{l}\text { Principle } \\
\text { Criterion } \\
\text { Indicator }\end{array}$} & \multicolumn{8}{|c|}{$\begin{array}{l}\text { 1. Meaningful Participation } \\
\frac{\text { Maximum score: } 25 ;}{\text { Minimum: } 5}\end{array}$} & \multicolumn{9}{|c|}{$\begin{array}{l}\frac{2 . \text { Productive deliberation }}{\text { Maximum score: } 30} \\
\text { Minimum: } 6\end{array}$} & \multirow[t]{3}{*}{$\begin{array}{l}\text { Total } \\
\text { (out } \\
\text { of } 55 \text { ) }\end{array}$} \\
\hline & \multicolumn{4}{|c|}{$\begin{array}{l}\text { 1. Interest representation } \\
\text { Maximum score: } 15 \\
\text { Minimum: } 3\end{array}$} & \multicolumn{3}{|c|}{$\begin{array}{l}\text { 2. Organisational responsibility } \\
\text { Maximum score: } 10 \\
\text { Minimum: } 2\end{array}$} & \multirow[t]{2}{*}{$\frac{\text { Principle }}{\text { Score }}$} & \multicolumn{4}{|c|}{$\begin{array}{l}\text { 3. Decision-making } \\
\text { Maximum score: } 15 \\
\text { Minimum: } 3\end{array}$} & \multicolumn{4}{|c|}{$\begin{array}{l}\text { 4. Implementation } \\
\text { Maximum score: } 15 \\
\text { Minimum: } 3\end{array}$} & \multirow[t]{2}{*}{$\frac{\text { Principle }}{\underline{\text { Score }}}$} & \\
\hline & $\begin{array}{l}\text { Inclus- } \\
\text { iveness }\end{array}$ & $\begin{array}{l}\text { Equal- } \\
\text { ity }\end{array}$ & $\begin{array}{l}\text { Resour- } \\
\text { ces }\end{array}$ & $\begin{array}{l}\text { Criterion } \\
\text { Score }\end{array}$ & $\begin{array}{l}\text { Account- } \\
\text { ability }\end{array}$ & $\begin{array}{c}\text { Trans- } \\
\text { parency }\end{array}$ & $\begin{array}{c}\text { Criterion } \\
\text { Score }\end{array}$ & & $\begin{array}{l}\text { Demo- } \\
\text { cracy }\end{array}$ & $\begin{array}{c}\text { Agree- } \\
\text { ment }\end{array}$ & $\begin{array}{c}\text { Dispute } \\
\text { settle- } \\
\text { ment }\end{array}$ & $\begin{array}{l}\text { Criterion } \\
\text { Score }\end{array}$ & $\begin{array}{l}\text { Behav- } \\
\text { ioural } \\
\text { change }\end{array}$ & $\begin{array}{l}\text { Problem } \\
\text { solving }\end{array}$ & $\begin{array}{l}\text { Dura- } \\
\text { bility }\end{array}$ & $\begin{array}{l}\text { Criterion } \\
\text { Score }\end{array}$ & & \\
\hline \multirow{2}{*}{$\begin{array}{l}\text { Environment } \\
\text { North } 6 \text { (19) }\end{array}$} & 2.67 & 1.83 & 1.00 & 5.50 & 2.60 & 2.67 & 5.27 & $\underline{10.77}$ & 2.20 & 2.17 & $2.20 e^{5}$ & 6.57 & 2.60 & 2.60 & 2.67 & 7.87 & 14.44 & 25.21 \\
\hline & 2.58 & 1.83 & 1.59 & 6.00 & 2.76 & 2.76 & 5.52 & $\underline{11.52}$ & 2.33 & 2.29 & 2.15 & 6.77 & 2.83 & 2.53 & 3.44 & 8.80 & 15.57 & 27.09 \\
\hline \multirow{2}{*}{$\begin{array}{l}\text { Environment: } \\
\text { South } 17 \text { (5) }\end{array}$} & 3.25 & 2.67 & 2.17 & 8.09 & 3.46 & 3.36 & 6.82 & $\underline{14.91}$ & 2.71 & 2.88 & 2.54 & 8.13 & 3.06 & 2.94 & 3.38 & 9.38 & $\underline{17.51}$ & 32.42 \\
\hline & 2.60 & 3.00 & 1.80 & 7.40 & 2.00 & 2.40 & 4.40 & 11.80 & 2.25 & 2.00 & 2.00 & 6.25 & 2.60 & 3.00 & 3.00 & 8.60 & $\underline{14.85}$ & 26.65 \\
\hline \multirow{2}{*}{$\begin{array}{l}\text { Weighted } \\
\text { Average }\end{array}$} & 3.10 & 2.45 & 1.86 & 7.41 & 3.24 & 3.18 & 6.42 & $\underline{13.83}$ & 2.58 & 2.69 & 2.45 & 7.72 & 2.94 & 2.85 & 3.19 & 8.99 & $\underline{16.71}$ & 30.54 \\
\hline & 2.58 & 2.07 & 1.63 & 6.29 & 2.60 & 2.69 & 5.29 & $\underline{11.58}$ & 2.31 & 2.23 & 2.12 & 6.66 & 2.78 & 2.63 & 3.35 & 8.76 & 15.42 & 27.00 \\
\hline \multirow{2}{*}{$\begin{array}{l}\text { Government } \\
\text { North } 3 \text { (1) }\end{array}$} & 3.33 & 4.00 & 1.00 & 8.33 & 3.00 & 3.67 & 6.67 & 15.00 & 3.33 & 2.67 & 2.33 & 8.33 & 3.67 & 3.67 & 3.00 & 10.34 & 18.67 & 33.67 \\
\hline & 5.00 & 4.00 & 1.00 & 10.00 & 3.00 & 4.00 & 7.00 & $\underline{17.00}$ & 4.00 & 4.00 & 4.00 & 12.00 & 4.00 & 4.00 & 5.00 & 13.00 & $\underline{25.00}$ & 42.00 \\
\hline \multirow{2}{*}{$\begin{array}{l}\text { Government } \\
\text { South } 10(5)\end{array}$} & 3.50 & 3.10 & 2.33 & 8.93 & 3.30 & 2.80 & 6.10 & $\underline{15.03}$ & 2.80 & 3.40 & 2.78 & 8.98 & 3.70 & 3.50 & 3.60 & 10.80 & $\underline{19.78}$ & 34.81 \\
\hline & 3.20 & 2.60 & 2.20 & 8.00 & 3.25 & 3.20 & 6.45 & $\underline{14.45}$ & 3.20 & 3.00 & 2.50 & 8.70 & 2.60 & 2.40 & 2.80 & 7.80 & $\underline{16.50}$ & 30.95 \\
\hline \multirow{2}{*}{$\begin{array}{l}\text { Weighted } \\
\text { Average }\end{array}$} & 3.46 & 3.31 & 2.02 & 8.79 & 3.23 & 3.00 & 6.23 & 15.02 & 2.92 & 3.23 & 2.68 & 8.83 & 3.69 & 3.54 & 3.46 & 10.69 & 19.52 & 34.55 \\
\hline & 3.50 & 2.83 & 2.00 & 8.33 & 3.21 & 3.33 & 6.54 & 14.88 & 3.33 & 3.17 & 2.75 & 9.25 & 2.83 & 2.67 & 3.17 & 8.67 & $\underline{17.92}$ & 32.79 \\
\hline \multirow{2}{*}{$\begin{array}{l}\text { Combined } \\
\text { Weighted } \\
\text { Averages }\end{array}$} & 3.23 & 2.76 & 1.92 & 7.91 & 3.23 & 3.12 & 6.35 & 14.26 & 2.70 & 2.89 & 2.53 & 8.12 & 3.21 & 3.10 & 3.29 & 9.60 & 17.73 & 31.99 \\
\hline & 2.77 & 2.23 & 1.71 & 6.70 & 2.72 & 2.81 & 5.54 & $\underline{12.24}$ & 2.52 & 2.42 & 2.25 & 7.18 & 2.79 & 2.64 & 3.31 & 8.74 & $\underline{15.92}$ & 28.16 \\
\hline
\end{tabular}


Table 3: UN-REDD related questionnaire (figures in brackets and aqua blue colour contain the results of the first survey)

\begin{tabular}{|c|c|c|c|c|c|c|c|c|c|c|c|c|c|c|c|c|c|c|}
\hline Principle & \multicolumn{8}{|c|}{$\frac{\text { 1. Meaningful Participation }}{\frac{\text { Maximum score: } 25 ;}{\text { Minimum: } 5}}$} & \multicolumn{9}{|c|}{$\frac{\text { 2. Productive deliberation }}{\frac{\text { Maximum score: } 30}{\text { Minimum: } 6}}$} & \multirow[t]{3}{*}{$\begin{array}{l}\text { Total } \\
\text { (out } \\
\text { of } \\
55 \text { ) }\end{array}$} \\
\hline Criterion & \multicolumn{4}{|c|}{$\begin{array}{l}\text { 1. Interest representation } \\
\text { Maximum score: } 15 \\
\text { Minimum: } 3\end{array}$} & \multicolumn{3}{|c|}{$\begin{array}{l}\text { 2. Organisational responsibility } \\
\text { Maximum score: } 10 \\
\text { Minimum: } 2\end{array}$} & \multirow[t]{2}{*}{$\frac{\text { Principle }}{\underline{\text { Score }}}$} & \multicolumn{4}{|c|}{$\begin{array}{l}\text { 3. Decision-making } \\
\text { Maximum score: } 15 \\
\text { Minimum: } 3\end{array}$} & \multicolumn{4}{|c|}{$\begin{array}{l}\text { 4. Implementation } \\
\text { Maximum score: } 15 \\
\text { Minimum: } 3\end{array}$} & \multirow[t]{2}{*}{$\frac{\text { Principle }}{\text { Score }}$} & \\
\hline Indicator & $\begin{array}{l}\text { Inclus- } \\
\text { iveness }\end{array}$ & $\begin{array}{l}\text { Equal- } \\
\text { ity }\end{array}$ & $\begin{array}{l}\text { Resour- } \\
\text { ces }\end{array}$ & $\begin{array}{l}\text { Criterion } \\
\text { Score }\end{array}$ & $\begin{array}{l}\text { Account- } \\
\text { ability }\end{array}$ & $\begin{array}{l}\text { Trans- } \\
\text { parency }\end{array}$ & $\begin{array}{c}\text { Criterion } \\
\text { Score }\end{array}$ & & $\begin{array}{l}\text { Demo- } \\
\text { cracy }\end{array}$ & $\begin{array}{c}\text { Agree- } \\
\text { ment }\end{array}$ & $\begin{array}{c}\text { Dispute } \\
\text { settle- } \\
\text { ment }\end{array}$ & $\begin{array}{l}\text { Criterion } \\
\text { Score }\end{array}$ & $\begin{array}{l}\text { Behav- } \\
\text { ioural } \\
\text { change }\end{array}$ & $\begin{array}{l}\text { Problem } \\
\text { solving }\end{array}$ & $\begin{array}{l}\text { Dura- } \\
\text { bility }\end{array}$ & $\begin{array}{c}\text { Criterion } \\
\text { Score }\end{array}$ & & \\
\hline \multirow{2}{*}{$\begin{array}{l}\text { Environment } \\
\text { North } 2(3)\end{array}$} & 4.00 & 3.00 & 2.00 & 9.00 & 2.00 & 3.00 & 5.00 & 14.00 & 3.00 & 3.00 & 3.00 & 9.00 & 4.00 & 2.50 & 2.00 & 8.50 & 17.50 & 31.50 \\
\hline & 4.00 & 3.00 & 1.00 & 8.00 & 4.00 & 3.33 & 7.33 & 15.33 & 4.00 & 2.67 & 2.00 & 8.67 & 3.67 & 3.00 & 2.67 & 9.34 & 18.01 & 33.34 \\
\hline \multirow{2}{*}{$\begin{array}{l}\text { Environment } \\
\text { South } 8 \text { (2) }\end{array}$} & 3.38 & 3.43 & 3.40 & 20.21 & 3.43 & 2.88 & 6.31 & $\underline{16.52}$ & 3.25 & 3.25 & 2.86 & 9.36 & 3.38 & 3.13 & 3.25 & 9.76 & $\underline{19.12}$ & 35.64 \\
\hline & 3.00 & 3.50 & 4.00 & 10.50 & 4.00 & 4.00 & 8.00 & 18.50 & 4.00 & 4.00 & 3.00 & 11.00 & 3.50 & 3.50 & 4.00 & 11.00 & $\underline{22.00}$ & 40.50 \\
\hline \multirow{2}{*}{$\begin{array}{l}\text { Weighted } \\
\text { Average }\end{array}$} & 3.50 & 3.34 & 3.12 & 17.97 & 3.14 & 2.90 & 6.05 & 16.02 & $3.20^{-}$ & 3.20 & 2.89 & 9.29 & 3.50 & 3.00 & 3.00 & 9.51 & 18.80 & 34.81 \\
\hline & 3.60 & 3.20 & 2.20 & 9.00 & 4.00 & 3.60 & 7.60 & 16.60 & 4.00 & 3.20 & 2.40 & 9.60 & 3.60 & 3.20 & 3.20 & 10.00 & 19.61 & 36.20 \\
\hline \multirow{2}{*}{$\begin{array}{l}\text { Government } \\
\text { North } 2 \text { (1) }\end{array}$} & 4.50 & 4.00 & 4.00 & 12.50 & 3.50 & 4.00 & 7.50 & $\underline{20.00^{\circ}} \cdot$ & 4.00 & 4.00 & 4.00 & 12.00 & 3.50 & 4.00 & 4.00 & 11.50 & $\underline{23.50}$ & 43.50 \\
\hline & (N/A) & 5.00 & (N/A) & $(N / A)$ & 4.00 & 5.00 & 9.00 & $(\mathrm{~N} / \mathrm{A})$ & 5.00 & 4.00 & 4.00 & 13.00 & 4.00 & 4.00 & 4.00 & 12.00 & 25.00 & (N/A) \\
\hline \multirow{2}{*}{$\begin{array}{l}\text { Government } \\
\text { South } 6(1)\end{array}$} & 3.17 & 3.17 & 2.33 & 8.67 & 3.33 & 3.33 & 6.66 & 15.33 & 3.17 & 3.60 & 3.60 & 10.37 & 3.80 & 3.80 & 4.00 & 11.60 & $\underline{21.97}$ & 37.30 \\
\hline & 4.00 & 4.00 & 3.00 & 11.00 & 4.00 & 5.00 & 9.00 & $\underline{20.00}$ & 4.00 & 4.00 & N/A & (N/A) & 3.00 & 3.00 & 4.00 & 10.00 & $(\mathrm{~N} / \mathrm{A})$ & (N/A) \\
\hline \multirow{2}{*}{$\begin{array}{l}\text { Weighted } \\
\text { Average }\end{array}$} & 3.50 & 3.38 & 2.75 & 9.63 & 3.37 & 3.50 & 6.87 & 16.50 & 3.38 & 3.70 & 3.70 & 10.78 & 3.73 & 3.85 & 4.00 & 11.58 & 22.35 & 38.85 \\
\hline & (N/A) & 4.50 & (N/A) & (N/A) & 4.00 & 5.00 & 9.00 & $(\mathrm{~N} / \mathrm{A})$ & 4.50 & 4.00 & (N/A) & (N/A) & 3.50 & 3.50 & 4.00 & 11.00 & $(\mathrm{~N} / \mathrm{A})$ & (N/A) \\
\hline \multirow{2}{*}{$\begin{array}{l}\text { Combined weighted } \\
\text { Averages }\end{array}$} & 3.50 & 3.36 & 2.95 & 14.26 & 3.25 & 3.17 & 6.41 & 16.23 & 3.28 & 3.42 & 3.25 & 9.95 & 3.60 & 3.38 & 3.44 & 10.43 & 20.38 & 36.61 \\
\hline & (N/A) & 3.57 & (N/A) & $(N / A)$ & 4.00 & 4.00 & 8.00 & (N/A) & 4.14 & 3.43 & (N/A) & $(N / A)$ & 3.57 & 3.29 & 3.43 & 10.29 & $(\mathrm{~N} / \mathrm{A})$ & (N/A) \\
\hline
\end{tabular}


Table 4: FCPF related questionnaire (figures in brackets and aqua blue colour contain the results of the first survey)

\begin{tabular}{|c|c|c|c|c|c|c|c|c|c|c|c|c|c|c|c|c|c|c|}
\hline$\underline{\text { Principle }}$ & \multicolumn{8}{|c|}{$\frac{\text { 1. Meaningful Participation }}{\frac{\text { Maximum score: } 25 ;}{\text { Minimum: } 5}}$} & \multicolumn{9}{|c|}{$\frac{\text { 2. Productive deliberation }}{\frac{\text { Maximum score: } 30}{\text { Minimum: } 6}}$} & \multirow{3}{*}{$\begin{array}{l}\text { Total } \\
\text { (out } \\
\text { of } \\
55 \text { ) }\end{array}$} \\
\hline Criterion & \multicolumn{4}{|c|}{$\begin{array}{l}\text { 1. Interest representation } \\
\text { Maximum score: } 15 \\
\text { Minimum: } 3\end{array}$} & \multicolumn{3}{|c|}{$\begin{array}{l}\text { 2. Organisational responsibility } \\
\text { Maximum score: } 10 \\
\text { Minimum: } 2\end{array}$} & \multirow[t]{2}{*}{$\frac{\text { Principle }}{\underline{\text { Score }}}$} & \multicolumn{4}{|c|}{$\begin{array}{l}\text { 3. Decision-making } \\
\text { Maximum score: } 15 \\
\text { Minimum: } 3\end{array}$} & \multicolumn{4}{|c|}{$\begin{array}{l}\text { 4. Implementation } \\
\text { Maximum score: } 15 \\
\text { Minimum: } 3\end{array}$} & \multirow[t]{2}{*}{$\frac{\text { Principle }}{\underline{\text { Score }}}$} & \\
\hline Indicator & $\begin{array}{l}\text { Inclus- } \\
\text { iveness }\end{array}$ & $\begin{array}{c}\text { Equal- } \\
\text { ity }\end{array}$ & $\begin{array}{c}\text { Resour- } \\
\text { ces }\end{array}$ & $\begin{array}{c}\text { Criterion } \\
\text { Score }\end{array}$ & $\begin{array}{l}\text { Account- } \\
\text { ability }\end{array}$ & $\begin{array}{c}\text { Trans- } \\
\text { parency }\end{array}$ & $\begin{array}{c}\text { Criterion } \\
\text { Score }\end{array}$ & & $\begin{array}{l}\text { Demo- } \\
\text { cracy }\end{array}$ & $\begin{array}{c}\text { Agree- } \\
\text { ment }\end{array}$ & $\begin{array}{l}\text { Dispute } \\
\text { Settle- } \\
\text { ment }\end{array}$ & $\begin{array}{c}\text { Criterion } \\
\text { Score }\end{array}$ & $\begin{array}{l}\text { Behav- } \\
\text { ioural } \\
\text { change }\end{array}$ & $\begin{array}{l}\text { Problem } \\
\text { solving }\end{array}$ & $\begin{array}{l}\text { Dura- } \\
\text { bility }\end{array}$ & $\begin{array}{c}\text { Criterion } \\
\text { Score }\end{array}$ & & \\
\hline \multirow{2}{*}{$\begin{array}{l}\text { Environment } \\
\text { North } 2 \text { (1) }\end{array}$} & 3.00 & 2.00 & 1.00 & 6.00 & 2.00 & 3.00 & 5.00 & $\underline{11.00}$ & 3.50 & 3.00 & 3.00 & 9.50 & 2.50 & 2.50 & 2.00 & 7.00 & 16.50 & 27.50 \\
\hline & 3.00 & 4.00 & 2.00 & 9.00 & 1.00 & 1.00 & 2.00 & 11.00 & 1.00 & 2.00 & 2.00 & 5.00 & 3.00 & 3.00 & 3.00 & 9.00 & 14.00 & 25.00 \\
\hline \multirow{2}{*}{$\begin{array}{l}\text { Environment } \\
\text { South } 7 \text { (1) }\end{array}$} & 3.33 & 3.00 & 1.40 & 7.73 & 2.83 & 2.83 & 5.66 & 13.39 & $2.57^{5}$ & 2.43 & 2.20 & 7.20 & 3.00 & 2.83 & 3.40 & 9.23 & 16.43 & 29.82 \\
\hline & (N/A) & 1.00 & 1.00 & (N/A) & 1.00 & 1.00 & 2.00 & $(\mathrm{~N} / \mathrm{A})$ & 1.00 & 1.00 & (N/A) & $(N / A)$ & (N/A) & (N/A) & (N/A) & (N/A) & $(\mathrm{N} / \mathrm{A})$ & (N/A) \\
\hline \multirow{2}{*}{$\begin{array}{l}\text { Weighted } \\
\text { Average }\end{array}$} & 3.26 & 2.78 & 1.31 & 7.35 & 2.65 & 2.87 & 5.51 & 12.86 . & 2.78 & 2.56 & 2.38 & 7.71 & 2.89 & 2.76 & 3.09 & 8.73 & 16.45 & 29.30 \\
\hline & (N/A) & 2.50 & 1.50 & $(N / A)$ & 1.00 & 1.00 & 2.00 & $(\mathrm{~N} / \mathrm{A})$ & 1.00 & 1.50 & (N/A) & $(N / A)$ & (N/A) & (N/A) & (N/A) & (N/A) & $(\mathrm{N} / \mathrm{A})$ & (N/A) \\
\hline \multirow{2}{*}{$\begin{array}{l}\text { Government } \\
\text { North } 1 \text { (2) }\end{array}$} & 4.00 & 4.00 & 4.00 & 12.00 & 3.00 & 3.00 & 6.00 & 18.00 & 4.00 & 4.00 & 4.00 & 12.00 & 4.00 & 4.00 & 4.00 & 12.00 & $\underline{24.00}$ & 42.00 \\
\hline & 5.00 & 5.00 & 5.00 & 15.00 & 4.50 & 4.50 & 9.00 & $\underline{24.00}$ & 4.50 & 3.50 & 4.00 & 12.00 & 4.00 & 4.00 & 4.00 & 12.00 & $\underline{24.00}$ & 48.00 \\
\hline \multirow{2}{*}{$\begin{array}{l}\text { Government } \\
\text { South } 5(0)\end{array}$} & 2.60 & 2.20 & 3.20 & 8.00 & 3.20 & 2.80 & 6.00 & 14.00 & 3.00 & 2.80 & 2.40 & 8.20 & 2.80 & 2.60 & 2.80 & 8.20 & 16.40 & 30.40 \\
\hline & (N/A) & (N/A) & (N/A) & $(N / A)$ & (N/A) & (N/A) & (N/A) & $(\mathrm{N} / \mathrm{A})$ & (N/A) & (N/A) & (N/A) & (N/A) & (N/A) & (N/A) & (N/A) & (N/A) & $(\mathrm{N} / \mathrm{A})$ & (N/A) \\
\hline \multirow{2}{*}{$\begin{array}{l}\text { Weighted } \\
\text { Average }\end{array}$} & 2.83 & 2.50 & 3.33 & 8.67 & 3.17 & 2.83 & 6.00 & 14.67 & 3.17 & 3.00 & 2.67 & 8.83 & 3.00 & 2.83 & 3.00 & 8.83 & 17.67 & 32.33 \\
\hline & (N/A) & (N/A) & (N/A) & $(N / A)$ & (N/A) & (N/A) & $(N / A)$ & $(\mathrm{N} / \mathrm{A})$ & (N/A) & (N/A) & (N/A) & (N/A) & (N/A) & (N/A) & (N/A) & (N/A) & (N/A) & (N/A) \\
\hline \multirow{2}{*}{$\begin{array}{l}\text { Combined } \\
\text { weighted } \\
\text { Averages }\end{array}$} & 3.09 & 2.67 & 2.12 & 7.87 & 2.85 & 2.85 & 5.71 & 13.58 & 2.93 & 2.73 & 2.49 & 8.16 & 2.93 & 2.79 & 3.05 & 8.77 & 16.93 & 30.52 \\
\hline & (N/A) & (N/A) & (N/A) & (N/A) & (N/A) & (N/A) & (N/A) & $(\mathrm{N} / \mathrm{A})$ & (N/A) & (N/A) & (N/A) & (N/A) & (N/A) & (N/A) & (N/A) & (N/A) & $(\mathrm{N} / \mathrm{A})$ & (N/A) \\
\hline
\end{tabular}


Table 5: REDD-plus 'consensus legitimacy rating' across indicators and sub-institutions as rated by environmental and governmental sectors (global north and south; Post COP-15, only) (figures in brackets and aqua blue colour contain the results of the first survey)

\begin{tabular}{|c|c|c|c|c|c|c|c|c|c|c|c|c|c|c|c|c|c|c|}
\hline$\underline{\text { Principle }}$ & \multicolumn{8}{|c|}{$\frac{\frac{1 .}{\text { Meaningful Participation }}}{\frac{\text { Maximum score: } 25 ;}{\text { Minimum: } 5}}$} & \multicolumn{9}{|c|}{$\frac{\text { 2. Productive deliberation }}{\frac{\text { Maximum score: } 30}{\text { Minimum: } 6}}$} & \multirow{3}{*}{$\begin{array}{l}\text { Total } \\
\text { (out o } \\
55 \text { ) }\end{array}$} \\
\hline Criterion & \multicolumn{4}{|c|}{$\begin{array}{l}\text { 1. Interest representation } \\
\text { Maximum score: } 15 \\
\text { Minimum: } 3\end{array}$} & \multicolumn{3}{|c|}{$\begin{array}{l}\text { 2. Organisational responsibility } \\
\text { Maximum score: } 10 \\
\text { Minimum: } 2\end{array}$} & \multirow[t]{2}{*}{$\frac{\text { Principle }}{\text { Score }}$} & \multicolumn{4}{|c|}{$\begin{array}{l}\text { 3. Decision-making } \\
\text { Maximum score: } 15 \text { es } \\
\text { Minimum: } 3\end{array}$} & \multicolumn{4}{|c|}{$\begin{array}{l}\text { 4. Implementation } \\
\text { Maximum score: } 15 \\
\text { Minimum: } 3\end{array}$} & \multirow[t]{2}{*}{$\frac{\text { Principle }}{\text { Score }}$} & \\
\hline Indicator & $\begin{array}{l}\text { Inclus- } \\
\text { iveness }\end{array}$ & $\begin{array}{l}\text { Equal- } \\
\text { ity }\end{array}$ & $\begin{array}{c}\text { Resour- } \\
\text { ces }\end{array}$ & $\begin{array}{c}\text { Criterion } \\
\text { Score }\end{array}$ & $\begin{array}{l}\text { Account- } \\
\text { ability }\end{array}$ & $\begin{array}{c}\text { Trans- } \\
\text { parency }\end{array}$ & $\begin{array}{c}\text { Criterion } \\
\text { Score } \\
\end{array}$ & & $\begin{array}{l}\text { Demo- } \\
\text { cracy }\end{array}$ & $\begin{array}{c}\text { Agree- } \\
\text { ment }\end{array}$ & $\begin{array}{l}\text { Dispute } \\
\text { settle- } \\
\text { ment }\end{array}$ & $\begin{array}{c}\text { Criterion } \\
\text { Score }\end{array}$ & $\begin{array}{l}\text { Behav- } \\
\text { ioural } \\
\text { change }\end{array}$ & $\begin{array}{c}\text { Problem } \\
\text { solving }\end{array}$ & $\begin{array}{l}\text { Dura- } \\
\text { bility }\end{array}$ & $\begin{array}{l}\text { Criterion } \\
\text { Score }\end{array}$ & & \\
\hline \multirow{2}{*}{$\begin{array}{l}\text { UNFCCC- } \\
\text { REDD-plus } \\
36(30)\end{array}$} & 3.23 & 2.76 & 1.92 & 7.91 & 3.23 & 3.12 & 6.35 & $\underline{14.26}$ & 2.7 & 2.89 & 2.53 & 8.12 & 3.21 & 3.1 & 3.29 & 9.6 & $\underline{17.73}$ & 31.99 \\
\hline & 2.77 & 2.23 & 1.71 & 6.7 & 2.72 & 2.81 & 5.54 & $\underline{12.24}$ & 2.52 & 2.42 & 2.25 & 7.18 & 2.79 & 2.64 & 3.31 & 8.74 & $\underline{15.92}$ & 28.16 \\
\hline \multirow{2}{*}{$\begin{array}{l}\text { UN-REDD } \\
18(7)\end{array}$} & 3.5 & 3.36 & 2.95 & 9.81 & 3.25 & 3.17 & 6.42 & 16.23 & 3.28 & 3.42 & 3.25 & 9.95 & 3.6 & 3.38 & 3.44 & 10.43 & 20.38 & 36.61 \\
\hline & (N/A) & 3.57 & (N/A) & $(N / A)$ & 4 & 4 & 8 & $(N / A)$ & 4.14 & 3.43 & (N/A) & (N/A) & 3.57 & 3.29 & 3.43 & 10.29 & (N/A) & (N/A) \\
\hline \multirow{2}{*}{$\begin{array}{l}\text { FCPF } \\
15(4)\end{array}$} & 3.09 & 2.67 & 2.12 & 7.87 & 2.85 & 2.85 & 5.71 & 13.58 & 2.93 & 2.73 & 2.49 & 8.16 & 2.93 & 2.79 & 3.05 & 8.77 & 16.93 & 30.52 \\
\hline & (N/A) & (N/A) & (N/A) & (N/A) & (N/A) & (N/A) & (N/A) & (N/A) & (N/A) & (N/A) & (N/A) & (N/A) & (N/A) & (N/A) & (N/A) & (N/A) & (N/A) & (N/A) \\
\hline \multirow{2}{*}{$\begin{array}{l}\text { Overall } \\
\text { weighted } \\
\text { averages }\end{array}$} & 3.27 & 2.90 & 2.23 & 9.56 & 3.15 & 3.07 & $6.23 \bigcirc$ & 14.63 & 2.90 & 2.99 & 2.71 & 8.61 & 3.25 & 3.11 & 3.28 & 9.64 & 18.25 & 32.88 \\
\hline & (N/A) & (N/A) & (N/A) & (N/A) & (N/A) & (N/A) & (N/A) & (N/A) & (N/A) & (N/A) & (N/A) & (N/A) & (N/A) & (N/A) & (N/A) & (N/A) & (N/A) & (N/A) \\
\hline
\end{tabular}




\section{About the Authors}

\section{Timothy Mark Cadman}

Is a graduate of Girton College Cambridge and holds a Doctorate from the School of Government in the University of Tasmania. He is the Sustainable Business Fellow in the Faculty of Business at the University of Southern Queensland, where he also lectures in politics, environmental policy, and sustainability. He is a Research Fellow with the Earth Systems Governance Project, and a Member of the Australian Centre for Sustainable Business and Development. He specialises in global environmental governance, natural resource management, and climate change policy. His book Quality and Legitimacy of Global Governance: Case Lessons from Forestry will be published in the Palgrave Macmillan International Political Economy Series in 2011. He can be contacted via email on tim.cadman@usq.edu.au.

\section{Tek Narayan Maraseni}

Is a Research Fellow with the Australian Centre for Sustainable Catchments and is working in the areas of climate change adaptation, mitigation, and GHG emissions accounting/modelling. He completed a double BSc (Science and Forestry) in Nepal (1985-1991), and gained his MSc in Natural Resources Management from Asian Institute of Technology, Thailand. His $\mathrm{PhD}$ on the carbon sequestration potential of different land use systems was completed at the University of Southern Queensland, Australia in 2007. His is the recipient of numerous awards and has over 60 publications to his name. 